\title{
Protein. synthesis in tissues of growing lambs
}

\author{
S. R. DAVIS, T. N. BARRY* AND G. A. HUGHSON \\ Ministry of Agriculture and Fisheries, Ruakura Agricultural Research Centre, \\ Hamilton, New Zealand
}

(Received 7 November 1980 - Accepted 11 April 1981)

1. The fractional rate of prctein synthesis (FSR) in tissues of nine growing lambs (4-5 months of age) was estimated following continuous infusion of $\mathrm{L}-\left[4,5-{ }^{8} \mathrm{H}\right]$ leucine for a period of $7 \mathrm{~h}$. Minimum and upper estimates of FSR were obtained assuming that the specific radioactivity (SRA) of leucine in blood plasma and tissue homogenate respectively defined that of leucyl tRNA.

2. Mean upper estimates of tissue protein FSR (/d) were skin $0 \cdot 35$, longissimus dorsi muscle $0 \cdot 05$, biceps femoris muscle 0.04 , liver 0.54 , rumen $(0.79$, cardiac muscle 0.09 . Minimum estimates of tissue protein FSR ranged from 0.03 (muscle) to 0.15 (liver).

3. Plasma leucine flux was c.osely related to body protein content and dietary leucine absorption (r 0-94).

4. The rate of whole-body protein synthesis (WBS) derived from plasma leucine flux corrected for oxidation and localized recycling of leucine into protein was similar to that calculated from the sum of daily protein synthesis in individual tissues using the upper estimate of FSR, i.e. $610 \mathrm{~g} / \mathrm{d} v .581 \mathrm{~g} / \mathrm{d}$.

5. The estimate of WBS derived from plasma leucine flux directly $(241 \mathrm{~g} / \mathrm{d})$ was similar to that calculated from the sum of minimum estimates of daily protein synthesis in individual tissues $(214 \mathrm{~g} / \mathrm{d})$.

6. The ratio, intracellular leucine SRA:plasma leucine SRA tended to increase with increasing dietary leucine absorption in all tissues although these factors were only significantly correlated $(P<0.05)$ in cardiac muscle, skin and rumen. Such relationships suggest an increased exchange of plasma leucine with intracellular leucine with increased food intake.

7. It was estimated that the energy cost of protein synthesis accounted for approximately $42 \%$ of daily heat production.

The mechanisms by which the rate of protein deposition is controlled in growing animals are of importance to the development of techniques to improve the efficiency of animal production. The rate of protein deposition represents the balance between the rates of protein synthesis and degradation (protein turnover), and studies carried out in laboratory and farm animals have indicated that the rate of protein synthesis is several times greater than the rate of deposition (Waterlow et al. 1978).

Among the classes of farm livestock in which studies of protein turnover have been reported are pigs (Garlick et al. 1976; Edmunds et al. 1978; Simon et al. 1978; Reeds \& Lobley, 1980), sheep (Soltesz et al. 1973; Buttery et al. 1975; Arnal, 1977; Buttery et al. 1977) and cattle (Lobley et al. 1980). All these studies have shown marked differences in the fractional synthetic rate (FSR) of protein found in individual tissues.

The study reported below was carried out on growing lambs of similar live weight to those used by Buttery et al. (1977). However, in the present work additional information was obtained relating tissue protein FSR to the rate of protein deposition, and plasma leucine flux to leucine absorption from the small intestine. Further, because of the relatively high variability in tissue protein FSR found by Buttery et al. (1977) it was thought necessary to confirm or otherwise the high rates reported. High rates of protein turnover require a significant expenditure of energy (Millward, Garlick, Nnanyelugo et al. 1976) and therefore the relationship of turnover rate to the rate of protein deposition is significant because of the bearing this has on over-all heat production.

The continuous intravenous infusion of a suitable radioactive amino acid over a period

- Invermay Agricultural Research Centre, Private Bag, Mosgiel, New Zealand 
of several hours is a technique which has been extensively used to measure rates of protein synthesis in animal tissues, largely because of the simplicity of the calculations required (see Waterlow et al. 1978). This method was adopted for the present study using L-[4,5- $\left.{ }^{3} \mathrm{H}\right] l$ leucine as tracer amino acid. Leucine was chosen from those amino acids which meet the criteria required (see Nicholas et al. 1978; Waterlow et al. 1978) mainly for reasons of analytical expediency.

The quantitative validity of results obtained from the use of the continuous infusion technique is still open to debate (see Lobley \& Harris, 1977; Waterlow et al. 1978). However, it is at least possible to estimate upper and lower limits to the rates of protein synthesis in individual tissues.

The lambs used in the present experiment were part of a comparative slaughter trial investigating the effect of abomasal casein infusion on the rate of protein deposition in growing lambs given fresh ryegrass (Lolium perenne) ad lib. (Barry, 1981).

\section{METHODS}

\section{Animals}

Nine autumn-born, castrate male, Romney lambs were used. At the start of the experiment these animals were approximately 5 months of age and weighed approximately $16.0 \mathrm{~kg}$. $\mathrm{L}-\left[4,5-{ }^{3} \mathrm{H}\right]$ leucine was infused into three lambs at this stage and in the remaining six animals the infusions were carried out 11 weeks later. The latter six lambs had abomasal fistulas inserted at 4 months of age and three lambs were infused with casein ( $44 \mathrm{~g}$ sodium caseinate plus $0.5 \mathrm{~g} \mathrm{~L}$-methionine/d) and three with an equivalent volume of salt solution (containing sodium chloride and sodium hydrogen phosphate) over the 11-week experimental period, as reported by Barry (1981).

All lambs were housed individually in pens, offered fresh ryegrass/clover (Trifolium repens) pasture ad lib, and intakes (as dry matter (DM)) recorded daily. Approximately 1 week before the continuous infusion of leucine the lambs were transferred to metabolism crates and intake measured over the final $4 \mathrm{~d}$ of this period. All other management procedures were as reported by Barry (1981).

\section{Infusion procedure}

On the day before leucine infusion jugular catheters were inserted bilaterally into each lamb. The infusion catheter $(250 \mathrm{~mm})$ was twice the length of the catheter used for blood sampling in order to prevent the direct sampling of infusate.

L- $\left[4,5-{ }^{3} \mathrm{H}\right]$ leucine $(40-60 \mathrm{mCi} / \mathrm{mmol}$; batch no. 71 , obtained from The Radiochemical Centre, Amersham, Bucks., UK) was diluted in $200 \mathrm{ml}$ saline $(9 \mathrm{~g} \mathrm{NaCl} / \mathrm{l})$ and infused at a rate of approximately $100 \mu \mathrm{Ci} / \mathrm{h}$. All lambs were allowed access to fresh herbage ad lib. during the leucine infusion and, where appropriate, casein or control salt solutions were infused into the abomasum.

\section{Tissue and blood sampling}

Before the end of each infusion (approximately $7 \mathrm{~h}$ ) the lamb was anaesthetized with sodium pentobarbitone and samples (approximately $5 \mathrm{~g}$ ) of shaved skin and skeletal muscle (longissimus dorsi, biceps femoris) removed by biopsy. The infusion was stopped and the lamb killed by severing the blood vessels of the neck. Samples were then taken of rumen, liver and cardiac muscle. All tissue samples were frozen immediately in liquid nitrogen and stored at $-20^{\circ}$ until analysed. Following slaughter all tissue samples were removed within a $3 \mathrm{~min}$ period.

Blood samples $(10 \mathrm{ml})$ were taken at $20 \mathrm{~min}$ intervals for the first $2 \mathrm{~h}$ of infusion and every 30 min thereafter. Samples were kept on ice in heparinized tubes and the plasma harvested within $2 \mathrm{~h}$ and stored at $-20^{\circ}$ until analysis. 


\section{Analytical techniques}

Specific radioactivity (SRA) of leucine in tissues and plasma. All SRA determinations were carried out on leucine fractionated by ion-exchange chromatography on a JEOL-6AH amino acid analyser (JEOL Co Ltd, Tokyo, Japan). Chromatography was carried out on a $500 \mathrm{~mm}$ column ( $9 \mathrm{~mm}$ diameter) containing JEOL-LCR-2 resin (sulphonated polystyrene beads, $10-11 \mu \mathrm{m}$ diameter). Each analysis was performed at a buffer flow rate of $0.95 \mathrm{ml} / \mathrm{min}$ using $0.2 \mathrm{M}$-sodium citrate buffer, $\mathrm{pH} \mathrm{4.2}$, at a column temperature of $55^{\circ}$. This procedure gave 'near biseline' separation of isoleucine, leucine, norleucine and tyrosine, and the leucine-containing fraction was collected by split-streaming the column eluate such that approximately half was diverted to a fraction collector while the remainder was reacted with ninhydrin for determination of leucine mass. Each complete analysis (including column regeneration) took $120 \mathrm{~min}$.

Preparation of tissues. Frozen tissue samples were cooled in liquid $\mathrm{N}_{2}$, pulverized, and homogenized in $8 \mathrm{ml}$ trichloracetic acid $(100 \mathrm{~g} / 1$; TCA) containing $0.5 \mu$ mol norleucine. The homogenate was centrifuged for $5 \mathrm{~min}$ at $750 \mathrm{~g}$ and the supernatant decanted. The precipitate was washed three times with $5 \mathrm{ml}$ TCA and the washings added to the supernatant fraction. The washed precipitate was freeze-dried and a portion of this material $(100 \mathrm{mg})$ hydrolysed for $24 \mathrm{~h}$ in $6 \mathrm{M}$-hydrochloric acid $(50 \mathrm{ml})$ under reflux. Following hydrolysis, $5 \mathrm{mg}$ norleucine was added to each flask and the hydrolysate rotary evaporated under vacuum to near dryness, washed three times with water, re-constituted in $100 \mathrm{ml}$ of water and stored at $-20^{\circ}$ before fractionation on the amino acid analyser. The final volume for reconstitution was reduced for some tissues to increase the concentration of radioactivity in the sample. In these instances the ion-exchange column was overloaded with amino acid and, of the fraction collected, part was used for determination of ${ }^{3} \mathrm{H}$ content and part was re-analysed for leucine mass.

The supernatant fraction containing tissue free amino acids was extracted three times with $10 \mathrm{ml}$ diethyl ether to remove excess TCA, rotary evaporated and re-constituted in $3.0 \mathrm{ml}$ $0.01 \mathrm{M}-\mathrm{HCl}$.

Plasma samples. Plasma was deproteinized with an equal volume of sulphosalicyclic acid $(60 \mathrm{~g} / \mathrm{l})$ containing $0.1 u \mathrm{~mol}$ norleucine. Approximately $0.8 \mathrm{ml}$ plasma equivalent was analysed as described previously for determination of leucine SRA.

Determination of radioactivity. The fractions containing radioactive leucine collected from the amino acid analyser were bulked, rotary evaporated to dryness, re-constituted in $1 \mathrm{ml}$ water and transferred to a scintillation vial. The flask used for evaporation was rinsed thoroughly with $10 \mathrm{ml}$ scintillation fluid ('Aquasol'; New England Nuclear, USA) and added to the vial and sc.mple.

Radioactivity was determined by liquid-scintillation spectrometry in a Tracor 6890 liquid-scintillation counter at a counting efficiency of $30-35 \%$ (determined by external standard channels ratio;

\section{Radiochemical purity}

$\mathrm{L}-\left[4,5-{ }^{3} \mathrm{H}\right]$ leucine (batch no. 71 ) had a quoted D-leucine content of less than $1 \%$. Although this was not verified further the relatively constant plateau specific activity of leucine achieved in plasma world suggest that D-leucine, if present, was not accumulating with consequences to the accuracy of determination of FSR and plasma leucine flux (see Waterlow et al. 1978).

Purity of the leucine was determined by fractionating the original infusate solution on the amino acid analyser as described previously. Recovery of $95 \%$ of the loaded radioactivity was made with the leucine-containing fraction. Part of this fraction was re-analysed to determine analytical losises and recovery was found to be $100 \%$ 


\section{Calculations}

Plasma leucine flux. The flux of leucine in plasma was calculated from the formula

$$
I=F \cdot S_{P}
$$

where $I$ the rate of infusion of isotope $(\mu \mathrm{Ci} / \mathrm{h}), F$ is the flux $(\mathrm{mmol} / \mathrm{h})$ and $S_{p}$ is the plateau SRA of leucine in plasma $(\mu \mathrm{Ci} / \mathrm{mmol})$.

Protein FSR. The FSR in the tissues was calculated as described by Garlick et al. (1973) from the formula;

$$
\frac{S_{B}}{S_{i}}=\left(\frac{\lambda_{i}}{\lambda_{i}-k_{g}}\right)\left(\frac{1-e^{-k_{g} t}}{1-e^{-\lambda_{i} t}}\right)-\left(\frac{k_{s}}{\lambda_{i}-k_{s}}\right),
$$

where $S_{B}$ is the SRA of protein-bound leucine and $S_{i}$ the SRA of 'free' (homogenate) leucine in the tissues, $k_{s}$ is the FSR (/d), $t$ is the length of infusion (d) and $\lambda_{i}$ is the rate-constant describing the rise to plateau of the SRA of free leucine in the tissue.

Because $\lambda_{i}$ was not determined directly the approximations of Garlick et al. (1973) were used such that for muscle $\lambda_{i}=R k_{s}$, where $R$ is the concentration ratio, protein-bound leucine: free leucine in the tissue. For skin, liver and rumen $\lambda_{i}=\lambda_{p}$, where $\lambda_{p}$ is the rate-constant in the formula describing the rise to plateau of leucine SRA in plasma $\left(S_{p}\right)$ as;

$$
S_{p}=S_{p} \max \left(1-\mathrm{e}^{-\lambda} t^{t}\right)
$$

where $S_{p} \max$ is the plasma leucine plateau SRA and $t$ is the length of infusion (d).

Because the calculation of $k_{g}$ is relatively insensitive to variation in $\lambda_{p}$ the average $\lambda_{p}$ determined in the nine animals was used. This value was $\lambda_{p}=39 / \mathrm{d}$.

In view of the uncertainty relating to how closely 'free' leucine SRA $\left(S_{i}\right)$ equates with the SRA of leucyl tRNA (see Lobley \& Harris, 1977) an estimate of the FSR was calculated using equation no. 2 but substituting $S_{B}: S_{p}$ for $S_{B}: S_{i}$. The estimate of $k_{s}$ so derived will be referred to as the minimum FSR.

Leucine absorption from the small intestine. The rate of leucine absorption from the small intestine was calculated from the results of Macrae \& Ulyatt (1974) relating duodenal non-ammonia-N flow (D.NAN; $g / d$ ) to $N$ intake $(N ; g / d)$, thus

$$
\text { D. } N A N=0 \cdot 56 \mathrm{~N}+2 \cdot 7 \text {. }
$$

Leucine absorption from the small intestine was estimated assuming $75 \mathrm{~g}$ leucine $/ \mathrm{kg}$ crude protein (D. NAN $\times 6.25$ ) in the duodenal digesta and an apparent absorption of 0.73 (Macrae \& Ulyatt, 1974). Where applicable, the additional contribution of the sodium caseinate infusate $(44.0 \mathrm{~g} / \mathrm{d})$ to the duodenal leucine flow was calculated assuming a casein-leucine content of $101 \mathrm{~g} / \mathrm{kg}$ protein (Ling et al. 1961). The apparent absorption of casein-leucine was assumed to be 0.73 .

\section{RESULTS}

Food intake, body protein content and plasma leucine flux

Plasma leucine SRA rose rapidly to a maximum in all animals; the rate constant $\left(\lambda_{p}\right)$ describing the rise to plateau was $39 / \mathrm{d}$ (determined on combined data from the nine lambs). The plateau leucine SRA was calculated as the mean of SRA determinations on samples taken between $2 \mathrm{~h}$ and $7 \mathrm{~h}$ of infusion. The coefficient of variation of plateau leucine SRA varied from $7-24 \%$ in individual lambs (Table 1 ).

Plasma leucine flux was closely related to predicted leucine absorption $(r 0.93 ; P<0.01)$ and to body protein content $(r 0.88 ; P<0.01)$. Bivariate regression analysis of plasma leucine flux (mmol/d) against predicted leucine absorption $\left(\mathrm{mmol} / \mathrm{d} ; X_{1}\right)$ and body protein 
Protein synthesis in lambs

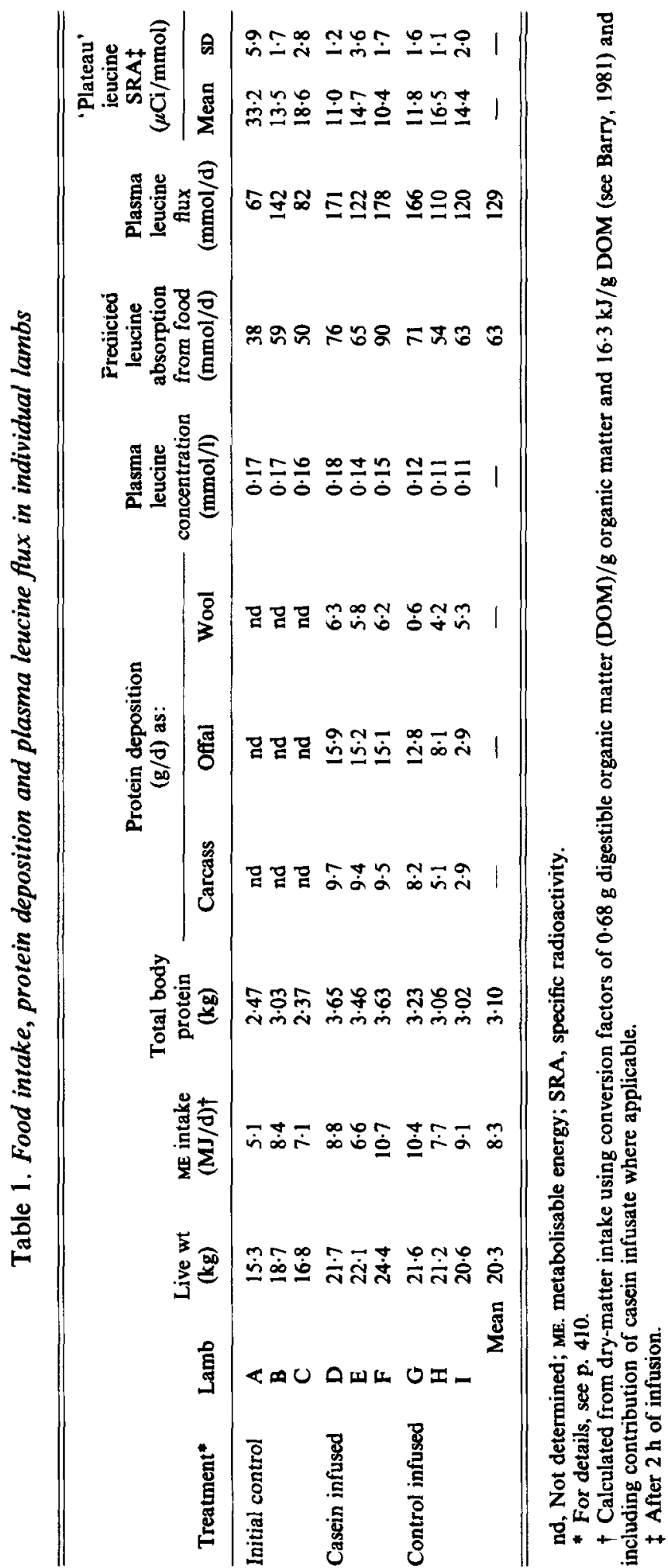


Table 2. Values for homogenate 'free' leucine specific radioactivity $(S R A)\left(\mathrm{S}_{1}\right)$ :plasma leucine $S R A\left(\mathrm{~S}_{\mathrm{p}}\right)(\times 100)$

(Values for homogenate leucine concentration (mmol/kg tissue) in parentheses)

\begin{tabular}{|c|c|c|c|c|c|c|c|}
\hline Treatment ${ }^{*}$ & Lamb & Skin & $\begin{array}{l}\text { Longissimus } \\
\text { dorsi }\end{array}$ & $\begin{array}{c}\text { Biceps } \\
\text { femoris }\end{array}$ & Liver & Rumen & Heart \\
\hline Initial control & $\begin{array}{l}\text { A } \\
\text { B } \\
\text { C }\end{array}$ & $\begin{array}{l}17(0.49) \\
39(0.42) \\
16(0.41)\end{array}$ & $\begin{array}{l}28(0.23) \\
73(0 \cdot 16) \\
42(0.20)\end{array}$ & $\begin{array}{l}37(0.22) \\
56(0.14) \\
64(0.18)\end{array}$ & $\begin{array}{l}15(0.53) \\
39(0.60) \\
27(1.00)\end{array}$ & $\begin{array}{l}14(0.80) \\
18(1.17) \\
15(0.88)\end{array}$ & $\begin{array}{l}36(0.30) \\
60(0 \cdot 32) \\
61(0 \cdot 27)\end{array}$ \\
\hline Casein infused & $\begin{array}{l}\mathrm{D} \\
\mathrm{E} \\
\mathrm{F}\end{array}$ & $\begin{array}{l}31(0.50) \\
39(0.61) \\
71(0.27)\end{array}$ & $\begin{array}{l}66(0.21) \\
48(0.22) \\
61(0.21)\end{array}$ & $\begin{array}{l}60(0.19) \\
55(0.27) \\
73(0.15)\end{array}$ & $\begin{array}{l}47(0.51) \\
23(0.95) \\
38(0.50)\end{array}$ & $\begin{array}{l}20(0.91) \\
26(0.74) \\
53(0.30)\end{array}$ & $\begin{array}{l}67(0.24) \\
61(0 \cdot 30) \\
98(0 \cdot 18)\end{array}$ \\
\hline \multirow[t]{2}{*}{ Control infused } & $\begin{array}{l}\text { G } \\
\text { H } \\
\text { I }\end{array}$ & $\begin{array}{l}41(0 \cdot 34) \\
33(0 \cdot 66) \\
39(0 \cdot 17)\end{array}$ & $\begin{array}{l}41(0.11) \\
43(0.17) \\
64(0.16)\end{array}$ & $\begin{array}{l}85(0.14) \\
77(0.14) \\
64(0.18)\end{array}$ & $\begin{array}{l}19(0-40) \\
28(0-66) \\
33(0-16)\end{array}$ & $\begin{array}{l}25(0.92) \\
23(0.53) \\
37(0.76)\end{array}$ & $\begin{array}{r}91(0.26) \\
100(0-12) \\
99(0.18)\end{array}$ \\
\hline & Mean & 36 & 52 & 63 & 30 & 26 & 75 \\
\hline
\end{tabular}

- For details, see p. 410.

Table 3. Upper estimate of tissue protein fractional synthetic rate (FSR) in individual lambs and mean minimum estimates

\begin{tabular}{|c|c|c|c|c|c|c|c|}
\hline \multirow[b]{2}{*}{ Treatment* } & \multirow[b]{2}{*}{ Lamb } & \multicolumn{6}{|c|}{ Tissue protein FSR (/d) } \\
\hline & & Skin & $\begin{array}{l}\text { Longissimus } \\
\text { dorsi }\end{array}$ & $\begin{array}{l}\text { Biceps } \\
\text { femoris }\end{array}$ & Liver & Rumen & Heart \\
\hline Initial control & $\begin{array}{l}\text { A } \\
\mathbf{B} \\
\mathbf{C}\end{array}$ & $\begin{array}{l}0.24 \\
0.27 \\
0.68\end{array}$ & $\begin{array}{l}0.02 \\
0.04 \\
0.07\end{array}$ & $\begin{array}{l}0.04 \\
0.04 \\
0.04\end{array}$ & $\begin{array}{l}0.80 \\
0.24 \\
0.53\end{array}$ & $\begin{array}{l}1.01 \\
1.02 \\
0.88\end{array}$ & $\begin{array}{l}0.09 \\
0.10 \\
0.08\end{array}$ \\
\hline Casein control & $\begin{array}{l}D \\
E \\
F\end{array}$ & $\begin{array}{l}0.43 \\
0.33 \\
0.28\end{array}$ & $\begin{array}{l}0.04 \\
0.05 \\
0.05\end{array}$ & $\begin{array}{l}0.04 \\
0.04 \\
0.04\end{array}$ & $\begin{array}{l}0.26 \\
0.43 \\
0.42\end{array}$ & $\begin{array}{l}1 \cdot 50 \\
0.50 \\
0.26\end{array}$ & $\begin{array}{l}0.10 \\
0.11 \\
0.07\end{array}$ \\
\hline Control infused & $\begin{array}{l}\mathbf{G} \\
\mathbf{H} \\
\mathbf{I}\end{array}$ & $\begin{array}{l}0.42 \\
0.38 \\
0.15\end{array}$ & $\begin{array}{l}0.07 \\
0.05 \\
0.04\end{array}$ & $\begin{array}{l}0.03 \\
0.04 \\
0.04\end{array}$ & $\begin{array}{l}0.96 \\
0.62 \\
0.59\end{array}$ & $\begin{array}{l}0.90 \\
0.43 \\
0.61\end{array}$ & $\begin{array}{l}0.11 \\
0.06 \\
0.06\end{array}$ \\
\hline $\begin{array}{l}\text { Mean (uppe } \\
\text { Mean (minimum }\end{array}$ & stimate) & $\begin{array}{l}0.35 \\
0.12\end{array}$ & $\begin{array}{l}0.05 \\
0.03\end{array}$ & $\begin{array}{l}0.04 \\
0.03\end{array}$ & $\begin{array}{l}0.54 \\
0.15\end{array}$ & $\begin{array}{l}0.79 \\
0 \cdot 14\end{array}$ & $\begin{array}{l}0.09 \\
0.06\end{array}$ \\
\hline
\end{tabular}

* For details, see p. 410.

$\dagger$ Calculated by substituting $S_{B}: S_{p}$ for $S_{B}: S_{i}$ in equation no. 2 (see p. 412 ).

content $\left(\mathrm{kg} ; X_{2}\right)$ showed that these factors accounted for $88 \%$ of the variation in plasma leucine flux between animals $(r 0.94)$ as described by the equation

$$
Y=1 \cdot 81 X_{1}+21 \cdot 7 X_{2}-52 \cdot 6 \text {. }
$$

However, body protein content and predicted leucine absorption were also significantly correlated $(r 0.88 ; P<0.01)$ and therefore the individual contribution of these two variables to leucine flux cannot be estimated with confidence from the regression analysis.

On the assumption that increments in leucine absorbed from the intestine contribute equally to the plasma leucine flux it may be calculated that, on average, there was a contribution of $63 \mathrm{mmol}$ leucine $/ \mathrm{d}$ from the diet to the plasma leucine flux of $129 \mathrm{mmol} / \mathrm{d}$ 
Table 4. Calculated rates of protein synthesis in individual tissues and estimates of whole-body rates

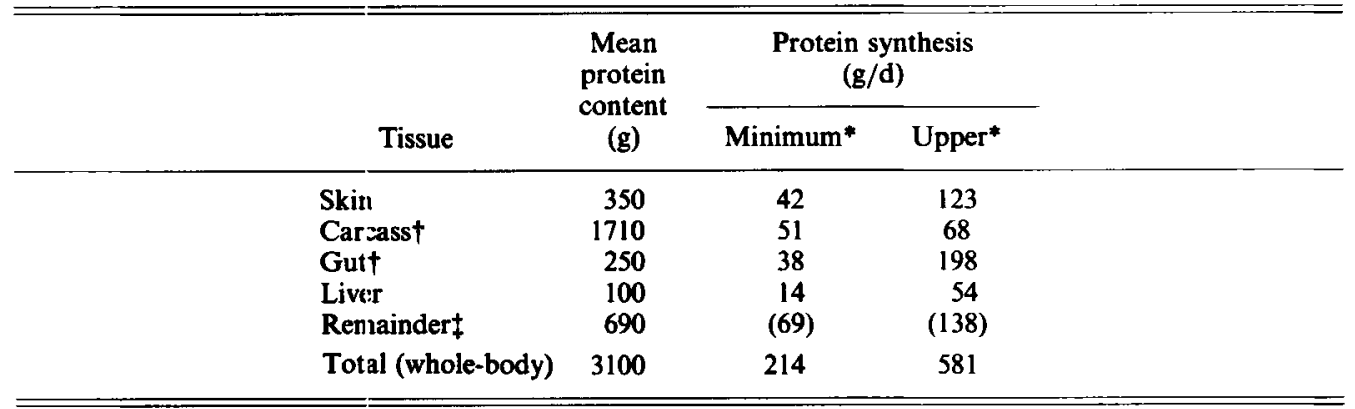

- Minimum or upper estimate of tissue protein fractional rate of synthesis (FSR): protein synthesis $(\mathrm{g} / \mathrm{d})=$ protein content $(\mathrm{g}) \times$ FSR $(/ \mathrm{d})$.

$\dagger$ Carcass protein synthesi; calculated using the average FSR of biceps and longissimus dorsi muscles; gut protein synthesis was calculated assuming the FSR of rumen applies to the whole alimentary tract.

$\ddagger$ An FSR of $0.1 / \mathrm{d}$ (mininum) and $0.2 / \mathrm{d}$ (upper) was assumed for the protein in the fraction consisting of brain, kidney, etc as a conservative estimate based on values obtained in other species.

(Table 1). However, the correlation of plasma leucine flux, corrected for dietary input, with total body protein content deteriorated by adopting this procedure $(r 0.81)$ although still statistically significant $(P<0.01)$.

\section{Free leucine in tissues and plasma}

The mean SRA of leucine extracted from the tissue homogenate varied from $26 \%$ (rumen) to $75 \%$ (heart) of the plateau leucine SRA in plasma (Table 2). The 'free' leucine concentration was always greater in tissues than in plasma, ranging up to a sixfold difference in the rumen wall (Tables 2 and 1 ).

The plasma concentration of leucine was higher in the casein-infused lambs than in the control-infused lambs but was similar to that found in the initial control group (Table 1).

The value for 'free' leıcine SRA:plasma leucine SRA $\left(S_{i}: S_{p}\right.$; Table 2) tended to increase with increasing dietary leucine absorption but the correlation only achieved statistical significance $(P<0.05)$ in skin, liver and heart tissues.

\section{Tissue protein FSR}

The FSR of protein in the sampled tissues is shown in Table 3. Highest values for FSR were determined in liver and rumen but between lamb variability was also greatest in these tissues.

The mean minimum estimate of FSR (see p. 412) for each tissue is also shown in Table 3. The greatest difference between the minimum and upper estimates of FSR were found in liver, rumen and skin.

Tissue protein FSR was not related to predicted leucine absorption from food, the rate of protein deposition or plasma leucine flux, neither were there any marked differences between the treatment groups.

\section{Estimate of whole-body protein synthesis from FSR measurements}

The rate of protein synthesis in an individual tissue was calculated as the product of FSR and protein content (Table 4). Summation of the rates for individual tissues gave an estimate of the whole-body rate of protein synthesis (WBS). Approximately $25 \%$ of total body 


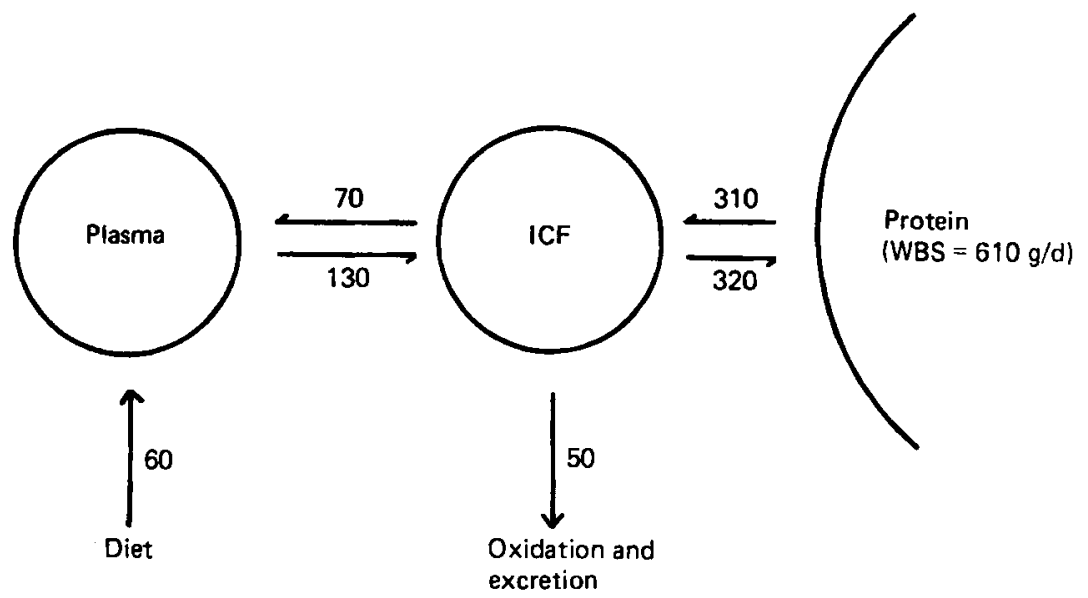

Fig. 1. Absolute flux rates of leucine (mmol/d) between plasma, intracellular fluid (ICF) and tissue protein. The rate of leucine loss by oxidation and excretion was assumed to be equivalent to the dietary input minus leucine deposited in protein. The rate of release of leucine by protein degradation was calculated assuming the specific radioactivity (SRA) of leucine in ICF to be $29 \%$ of plasma leucine and apportioning the relative contribution of leucine flux from plasma and protein accordingly. The SRA of leucine in ICF was calculated from the average SRA of homogenate 'free' leucine determined in individual tissues (Table 2) weighted for the contribution each makes to the total protein mass. This value was then corrected for an extracellular fluid content of $20 \%$, the SRA of leucine in the latter being assumed to be equivalent to that in plasma. Whole-body protein synthesis (WBS) was calculated assuming a leucine content in body protein of $70 \mathrm{~g} / \mathrm{kg}$ protein and using the plasma leucine flux $(130 \mathrm{mmol} / \mathrm{d})$ or the calculated flux of leucine from ICF into protein $(320 \mathrm{mmol} / \mathrm{d})$. The latter value is illustrated.

protein was not sampled necessitating assumptions to be made as to the FSR of protein in these tissues (see Table 4).

WBS was calculated using the upper and minimum estimates of tissue protein FSR, the former estimate of WBS being almost three times that of the latter (Table 4). The contribution of skeletal muscle to total daily protein synthesis was a relatively small percentage (12) of the total (using the upper estimates of FSR) while skin and intestinal protein together contributed over $50 \%$ of the total.

\section{Estimate of whole-body protein synthesis from plasma leucine fux}

The calculation of WBS directly from the plasma leucine flux is questionable because part of the plasma flux may contribute to oxidative pathways and because an unknown fraction of the leucine released by protein degradation is reincorporated into protein without passing through the plasma pool (localized recycling). Such errors act in opposite directions (Garlick et al. 1976), but still a high extent of uncertainty is left in the final answer.

The estimate of WBS derived from plasma leucine flux directly $(240 \mathrm{~g} / \mathrm{d}$; see Fig. 1) was similar to that derived previously using the minimum estimate of FSR (see Table 4). Thus the uncertainty which applies to the flux estimate of WBS casts doubt on accuracy of the estimate derived from minimum FSR. A further calculation of WBS from the plasma leucine flux corrected for the contribution of the flux to oxidative pathways and for the extent of localized recycling is summarized schematically in Fig. 1. The result obtained from applying such corrections (WBS $610 \mathrm{~g} / \mathrm{d}$ ) was considerably greater than that obtained directly from the flux, but similar to that derived using the upper estimate of FSR. 
Table 5. A summary of values for tissue protein fractional synthetic rate (FSR) in sheep

\begin{tabular}{|c|c|c|c|c|c|c|}
\hline \multirow[b]{2}{*}{ Source } & \multirow{2}{*}{$\begin{array}{l}\text { Approximate } \\
\text { live wt } \\
(\mathrm{kg})\end{array}$} & \multicolumn{5}{|c|}{ FSR $(\% / d)$} \\
\hline & & Skin & $\begin{array}{c}\text { Skeletal } \\
\text { muscle }\end{array}$ & $\begin{array}{l}\text { Cardiac } \\
\text { muscle }\end{array}$ & $\begin{array}{l}\text { Rumen } \\
\text { wall }\end{array}$ & Liver \\
\hline Present study & 20 & 35 & 5 & 9 & 79 & 54 \\
\hline Soltesz et al. (1973) & $3-7$ & nd & 23 & 34 & nd & 105 \\
\hline Buttery et al. (1977) & 20 & nd & 25 & 13 & 168 & 240 \\
\hline Buttery et al. (1975) & $40-50$ & nd & 2 & 16 & nd & 101 \\
\hline Arnal et al. (1977) & $20-30$ & nd & 4 & nd & nd & nd \\
\hline
\end{tabular}

nd, Not determined.

\section{DISCUSSION}

Tissue protein FSR

Studies of the rate of protein turnover in ovine tissues are summarized in Table 5. All these studies differ in the live weight of the animals used or methodology, particularly in the choice of the radioactive amino acid used for infusion, or both. Buttery et al. (1977) used lambs of a similar live weight "o those used here but a continuous infusion of $\mathrm{L}-\left[4,5-^{3} \mathrm{H}\right] l y s i n e$. The values obtained for tissue protein FSR were considerably greater than the present results for comparable tissues. Whether these discrepancies reflect dietary, methodological or environmental differences is unknown. Arnal (1977) reported that tissue protein FSR declined in lambs up to 16 weeks of age and at this stage of development the FSR of muscle protein was similar to that found in the present experiments.

The estimates of FSR for liver and rumen protein are compromised to the extent that the liver 'exports' a large part of its protein production and the rumen epithelium will lose whole cells by sloughing during the processes of digestion. Such phenomena will result in an underestimate of FSR and probably contribute to the variability of the FSR determinations in these tissues. Further, measurements of protein synthesis in tissues where protein turnover is rapid (e.g. gut and liver) are subject to error when the continuous infusion technique is used because of loss of labelled protein by turnover during the period of infusion (James et al. 1971). The technique described by McNurlan et al. (1979) is more suitable for tissues such as the gut and liver but is prohibitively expensive for use in large animals because of the massive cuantity of radioactive amino acid required.

Millward, Garlick \& Reeds (1976) suggested that the primary regulation of muscle protein content in rats is achieved through regulation of protein synthesis. This could not be confirmed in the present study as protein deposition (in the six lambs where it was measured) and protein FSR were not correlated. Failure to demonstrate such a correlation probably relates to the insensitivity of the technique. When the rate of protein deposition $(20-30 \mathrm{~g} / \mathrm{d}$; Table 1) is such a small proportion of the rate of protein synthesis $(600 \mathrm{~g} / \mathrm{d}$; Table 4$)$ only a small change in the latter will result in large changes in the rate of deposition if the rate of degradation remains constant. A similar sensitivity of protein deposition to the rate of degradation also applies. Nevertheless, the increase in plasma insulin concentration as a consequence of casein infusion (Barry et al. 1981) may reduce the rate of proteolysis in muscle (see Trenkle, 1974) and thus the increased rate of protein deposition in the casein-infused animals may be attributable, in part, to a reduced rate of protein degradation.

It has been suggested that leucine is rate-limiting for protein synthesis in rat muscle (Buse $\&$ Weigand, 1977). The results reported here do not support this contention for the skeletal muscles but there was a significant relationship between cardiac muscle leucine concentration 
and cardiac protein FSR $(r 0.81 ; P<0.01)$. Morgan et al. (1971) have demonstrated an increase in rate of peptide chain initiation in isolated perfused rat hearts in association with an increased concentration of leucine in the perfusate.

\section{The estimate of WBS}

The use of plasma amino acid flux to calculate the rate of WBS has been discussed elsewhere (Reeds \& Lobley, 1980). The estimate of WBS obtained from plasma leucine flux, adjusted for oxidative losses and localized recycling $(610 \mathrm{~g} / \mathrm{d} ; \mathrm{Fig}$. 1) was similar to that obtained from the upper estimate of tissue protein FSR ( $581 \mathrm{~g} / \mathrm{d}$; Table 4).

The validity of both higher values of WBS is dependent on how closely the estimates of homogenate leucine SRA $\left(S_{i}\right)$ and intracellular leucine SRA (Fig. 1) relate to the SRA of leucyl tRNA. The relative merits of using $S_{i}$ or $S_{p}$ to determine tissue protein FSR have been discussed by Lobley \& Harris (1977). The closer $S_{i}$ approaches $S_{p}$ the greater the confidence that may be placed in the final result. In the present study $S_{i}: S_{p}$ varied from 0.26 (rumen) to 0.75 (heart) thereby posing the question as to which factor is an accurate reflection of leucyl tRNA SRA.

There is good reason to doubt the accuracy of calculating WBS from plasma amino acid flux uncorrected for oxidation or localized recycling. The similarity of this value to the estimate of WBS derived from the minimum estimate of FSR suggests that the latter is also in error. The evidence of Airhart et al. (1974) and Fern \& Garlick (1974), supports the use of $S_{i}$ as a measure of leucyl tRNA SRA and adds credence to the values of WBS calculated from the upper estimates of FSR and from the corrected plasma leucine flux. The estimate of WBS of $610 \mathrm{~g} / \mathrm{d}$ represents the average value for lambs with a mean body-weight of $20.3 \mathrm{~kg}$. This value is considerably greater than the estimate of WBS calculated by Reeds $\&$ Lobley (1980) for a number of species, on the basis of the plasma flux of $\left[1-{ }^{14} \mathrm{C}\right]$ leucine corrected for catabolic losses. However, Reeds \& Lobley (1980) did not correct for localized recycling of leucine, apparently because of the problems involved in its approximation. Studies elsewhere with rats, where the upper estimates of FSR have been employed to calculate WBS, have derived a similar value of WBS per unit body-weight to that found here ( $38 \mathrm{~g} / \mathrm{d}$ per $\mathrm{kg}$, Webster et al. 1978).

$S_{i}: S_{p}$ increased with increasing leucine absorption from the diet in all tissues, although the correlation only achieved statistical significance in skin, rumen and heart. Such a relationship, however, infers that the contribution of plasma leucine to the leucine pool for protein synthesis increases with increasing nutritional status, this phenomenon tending to diminish the difference between $S_{p}$ and $S_{i}$. Further evidence in support of this contention is that increments in leucine absorption from food result in larger increments in plasma leucine flux (see p. 412) suggesting an increased exchange of leucine between tissues and plasma with increasing food intake. However, confirmation of this finding is required using animals of similar body protein content but differing widely in food intake.

\section{The energy cost of protein turnover}

The energy cost of protein deposition in lambs increases with the transition from the preruminant to ruminant state (Rattray \& Jagusch, 1977). The energy cost of protein turnover in the digestive tract of the ruminant might be expected to be greater than in the non-ruminant because of the relatively large muscle mass of the rumen and the high FSR of its protein (Table 3). A point worthy of consideration in relation to the FSR of rumen protein is whether the latter is associated with the muscle or epithelial layers and to what extent the protein synthesized utilizes amino acids from rumen fluid. The rumen has not been regarded as a major site of amino acid absorption (Leibholz, 1969) but recycling of amino acids between the rumen wall and rumen contents may occur to an appreciable extent. 
The energy cost of protein synthesis in the lambs used here may be calculated assuming an energy cost of $4.5 \mathrm{~kJ} / \mathrm{g}$ protein synthesized (Webster, 1976). For this purpose an estimate of WBS of $600 \mathrm{~g} / \mathrm{d}$ has been used (see previous discussion). Thus it can be calculated that the energy cost of protein synthesis in the lambs used here was $2.7 \mathrm{MJ} / \mathrm{d}$ or approximately $35 \%$ of metabolizable energy (ME) intake.

Webster et al. (1978) found a high correlation between heat loss $(\mathrm{kJ} / \mathrm{d})$ and protein synthesis $(\mathrm{g} / \mathrm{d})$. Heat production of the lambs used here may be estimated from the ME intake $(7.6 \mathrm{MJ} / \mathrm{d})$ less the daily deposition of tissue $(1.2 \mathrm{MJ} / \mathrm{d}$; Barry, 1981) as $6.4 \mathrm{MJ} / \mathrm{d}$. Heat production per unit protein synthesized $(10.7 \mathrm{~kJ} / \mathrm{g})$ is remarkably similar to the value reported by Webster et al. (1978) for rats, i.e. an increment of $11.8 \mathrm{KJ} / \mathrm{g}$ synthesized.

As the rate of protein turnover is approximately twenty times that of the rate of protein deposition small changes in the rate of protein synthesis or degradation will result in large changes in the rate of deposition. Such information questions the validity of the calculation of the energy cost of prctein deposition (e.g. Kielanowski, 1976) as protein deposition may increase with zero change in energy expenditure in protein synthesis.

\section{REFEREN CES}

Airhart, J., Vidrich, A. \& Khairallah, E. A. (1974). Biochem J. 140, 539.

Arnal, M. (1977). Publs Eur. Ass. Anim. Prod. 22, 35.

Barry, T. N. (1981). Br. J. Nitr. (In the Press.)

Barry, T. N. Manley, T. R., Redekopp, C. (1981). Proc. N.Z. Soc. Anim. Prod. (In the Press.)

Buse, M. G. \& Weigand, D. A. (1977). Biochem. biophys. Acta 475, 81.

Buttery, P. J., Beckerton, A. \& Lubbock, M. H. (1977). Publs Eur. Ass. Anim. Prod. $22,32$.

Buttery, P. J., Beckerton, A., Mitchell, R. M., Davies, K. \& Annison, E. F. (1975). Proc. Nutr. Soc. 34,91 A.

Edmunds, B. K., Buttery, P. .I. \& Fisher, C. (1978). Proc. Nutr. Soc. 37, 32A.

Fern, E. B. \& Garlick, P. J. (1974). Biochem. J. 142, 413.

Garlick, P. J., Burk, T. L. \& Swick, R. W. (1976). Am. J. Physiol. $230,1108$.

Garlick, P. J., Millward, D. J. \& James, W. P. T. (1973). Biochem. J. 136, 935.

James, W. P. T., Garlick, P. J. \& Millward, D. J. (1971). Gut 12, 495.

Kielanowski, J. (1976). In Piotein Metabolism and Nutrition [D. J. A. Cole, K. N. Boorman, P. J. Buttery, D. Lewis, R. J. Neale and H. Swan, editors]. London: Butterworth.

Leibholz, J. (1969). J. Anim. Sci. 29, 628.

Ling, E. R., Kon, S. K. \& Porter, J. W. G. (1961). In Milk: The Mammary Gland and its Secretion, vol. 2 [S. K. Kon and A. T. Cowie, editors]. London: Academic Press.

Lobley, G. E. \& Harris, C. I. (1977). Publs Eur. Ass. Anim. Prod. 22, 29.

Lobley, G. E., Milne, V., Lorie, J. M., Reeds, P. J. \& Pennie, K. (1980). Br. J. Nutr. 43, 491.

McNurlan, M. A., Tomkins, A. M. \& Garlick, P. J. (1979). Biochem. J. 178, 373.

MacRae, J. C. \& Ulyatt, M. J. (1974). J. agric. Sci., Camb. 82, 309.

Millward, D. J., Garlick, P. J., Nnanyelugo, D. O. \& Waterlow, J. C. (1976). Biochem. J. 156, 185.

Millward, D. J., Garlick, P. J. \& Reeds, P. J. (1976). Proc. Nutr. Soc. 35, 339.

Morgan, H. E., Jefferson, L. S., Wolpert, E. B. \& Rannels, D. E. (1971). J. biol. Chem. 246, 2163.

Nicholas, G. A., Lobley, G. E. \& Harris, C. I. (1978). Br. J. Nutr. 38, 1.

Rattray, P. V. \& Jagusch, K. T. (1977). Proc. N.Z. Soc. Anim. Prod. 37, 167.

Reeds, P. J. \& Lobley, G. E. (1980). Proc. Nutr. Soc. 39, 43.

Simon, O., Munchmeyer, R., Bergner, H., Zebrowska, T. \& Buraczewska, L. (1978). Br. J. Nutr. $40,243$.

Soltesz, G., Joyce, J. \& Young, M. (1973). Biol. Neonate 23, 139.

Trenkle, A. (1974). J. Anim. Sci. 38, 1142.

Waterlow, J. C., Garlick, P. J. \& Milward, D. J. (1978). Protein Turnover in Mammalian Tissues and in the Whole Body. Amsterdam: North Holland.

Webster, A. J. F. (1976). In Meat and Animals, Growth and Productivity, p. 89 [D. Lister, D. N. Rhodes, V. R. Fowler and M. F. Fuller, bditors]. London: Plenum.

Webster, A. J. F., Lobley, G., Reeds, P. J. \& Pullar, J. D. (1978). Proc. Nutr. Soc. 37, 21 A. 